\section{Treatment of mastalgia with bromocriptine: a double-blind cross-over study}

Mastalgia is often associated with fibrocystic disease of the breast. Treatments, however, often fail, probably owing to an unsatisfactory understanding of the nature of the condition. In this study we assess the therapeutic efficacy of bromocriptine.

\section{Patients, methods, and results}

Severe mastalgia was the dominant feature in 10 women with diffuse fibrocystic disease of the breast as judged by palpation and mammography and verified histologically. One patient (case 1) had galactorrhoea. None had prominent characteristics of the premenstrual syndrome. Mastalgia had been present for from six months to several years. In a double-blind crossover trial patients were allocated at random to receive either bromocriptine or identical placebo capsules, each for a period of two months, in a dose of one capsule (bromocriptine $2.5 \mathrm{mg}$ or placebo) daily during the first week of each period and thereafter two capsules daily. For one month before the trial and throughout the period of medication the presence and intensity of pain were recorded daily by each patient. They were seen in the outpatient clinic every four weeks. The code was broken at the end of each trial. Serum prolactin concentration was measured before the trial, on the day of crossover, and on the final day of the trial (normal range 3.0-13.5 $\mu \mathrm{g} / \mathrm{l}$ ).

During treatment with bromocriptine pain was totally or almost totally relieved in eight patients and in two the pain was much reduced (table) Placebo treatment failed to relieve mastalgia in any patient except one (case 9), in whom the relief during bromocriptine continued while taking placebo. Statistical analysis by Koch's method ${ }^{1}$ showed that the relief obtained during bromocriptine therapy was significantly greater $(P<0.02)$ than that during placebo medication, while period effects as well as carry-over effects were absent $(P>0.05)$. Mastalgia reappeared as soon as active medication was stopped, with the exception of the patient in case 9. The breasts became smaller, softer, and less tender during bromocriptine treatment.

The pretrial serum prolactin concentration was slightly raised in three patients and normal in seven. During treatment with bromocriptine these concentrations were significantly lowered $(P<0.01$, sign test). There were no side effects from placebo. While taking bromocriptine five patients had slight, transitory nausea and dizziness, which is a recognised side effect. Three others had persistent and more pronounced nausea, dizziness, and general malaise.

\section{Comment}

The significant beneficial effect of bromocriptine on mastalgia in women with fibrocystic disease of the breast in this controlled study accords with the findings in uncontrolled trials. ${ }^{2-4}$ Bromocriptine has also been found effective in premenstrual mastalgia when this is part of the premenstrual syndrome. ${ }^{5}$ But we do not know of any relationship between the premenstrual syndrome and fibrocystic disease. Although three of our patients had slightly raised serum prolactin concentrations, there is no evidence of major disturbances in prolactin secretion in patients with fibrocystic disease and mastalgia, ${ }^{2-4}$ and it is uncertain whether prolactin is of any pathogenetic importance. Patients with hyperprolactinaemia do not have mastalgia, probably owing to subnormal oestrogen and progesterone levels caused by prolactin-induced inhibition of gonadal function. It is unproved that the effect of bromocriptine is mediated through lowering of circulating concentrations of prolactin. This hormone has a mammotropic effect, and possibly lowering the serum prolactin concentration decreases the total stimulatory effect on the breasts and thus stops pain.

We thank Sandoz, Copenhagen, for bromocriptine and the National Pituitary Agency, National Institute of Arthritis, Metabolic and Digestive Diseases, for reagents for prolactin radioimmunoassay.

1 Koch, G G, Biometrics, 1972, 28, 577.

${ }^{2}$ Schulz, K-D, et al, Archiv für Gynäkologie, 1975, 220, 83.

3 Martin-Comin, J, et al, Obstetrics and Gynecology, 1976, 48, 703.

4 Palmer, B V, and Monteiro, J C M P, British Medical fournal, 1971, 1, 1083.

${ }^{5}$ Andersen, A N, et al, British fournal of Obstetrics and Gynaecology, 1977, 84, 370 .

(Accepted 15 November 1978)

Department of Surgical Gastroenterology, the Institute of Pathology, and the Department of Diagnostic Radiology, Herlev University Hospital, 2730 Copenhagen, Denmark

$M$ BLICHERT-TOFT, MD, DSC, senior surgeon

A NYBOE ANDERSEN, MD

O B HENRIKSEN, MD, senior pathologist

T MYGIND, MD, DSC, chief of diagnostic radiology

\section{Effect of once-daily atenolol on ambulatory blood pressure}

The technique of recording intra-arterial blood pressure in ambulant hypertensive patients throughout complete 24-hour periods ${ }^{12}$ has made it possible to study the effects of antihypertensive drugs throughout normal daily activities. The blood pressure follows a 24-hour circadian rhythm with the highest values in the morning and the lowest at night at about $3 \mathrm{am} .^{3}$ In the early morning there is a rise in pressure, particularly at the time of awakening, continuing up to a peak at about $10 \mathrm{am}$. This rhythm poses many questions about blood pressure "control" with therapeutic agents, particularly those that are thought to be effective with a single dose. Atenolol, a cardioselective beta-blocking drug with a half life of 6 to 9 hours, is claimed to have such an effect.

\section{Patients, methods, and results}

We studied six untreated patients (four men, two women) with confirmed essential hypertension aged 46 to 67 years (mean $59 \cdot 8$ ). Continuous ambulant intra-arterial blood pressure was measured with a new transducer-perfusion unit $^{2}$ from a brachial artery cannula inserted percutaneously under local anaesthesia. The blood pressure signal and the ECG were recorded on a miniature cassette recorder (Oxford Instruments Ltd). A complete 24-hour recording was carried out in each patient before treatment. The cannula was then removed and each patient was treated with enough atenolol once daily $($ at $8.30 \mathrm{am})$ to produce satisfactory clinic blood pressure "control"

Basic data and main results of treatment with bromocriptine and placebo in 10 women with severe mastalgia

\begin{tabular}{|c|c|c|c|c|c|c|c|c|c|}
\hline \multirow{2}{*}{$\begin{array}{l}\text { Case } \\
\text { No }\end{array}$} & \multirow{2}{*}{$\underset{\text { (years) }}{\text { Age }}$} & \multirow{2}{*}{$\begin{array}{l}\text { Menstrual } \\
\text { cycle }\end{array}$} & \multicolumn{2}{|c|}{ Mastalgia } & \multicolumn{2}{|c|}{ Intensity of mastalgia* } & \multicolumn{3}{|c|}{ Serum prolactin concentration $(\mu \mathrm{g} / \mathrm{l})$} \\
\hline & & & Pattern & Location & $\begin{array}{c}\text { Bromocriptine } \\
\text { (two months) }\end{array}$ & $\begin{array}{c}\text { Placebo } \\
\text { (two months) }\end{array}$ & Pretrial & Bromocriptine & Placebo \\
\hline $\begin{array}{l}1 \\
2\end{array}$ & $\begin{array}{l}30 \\
36\end{array}$ & $\begin{array}{l}\text { Regular } \\
\text { Regular }\end{array}$ & Cyclical & Unilateral & 0 & ++ & $6 \cdot 1$ & $3 \cdot 2$ & $5 \cdot 3$ \\
\hline $\begin{array}{l}3 \\
4 \\
5 \\
6\end{array}$ & $\begin{array}{l}37 \\
46 \\
34 \\
42\end{array}$ & $\begin{array}{l}\text { Regular } \\
\text { Regular } \\
\text { Regular } \\
\text { Regular }\end{array}$ & $\begin{array}{l}\text { Cyclical } \\
\text { Constant } \\
\text { Cyclical } \\
\text { Cyclical }\end{array}$ & $\begin{array}{l}\text { predominance } \\
\text { Bilateral } \\
\text { Bilateral } \\
\text { Bilateral } \\
\text { Unilateral }\end{array}$ & $\begin{array}{l}0 \\
+ \\
0 \\
+\end{array}$ & $\begin{array}{l}++ \\
++ \\
++ \\
++\end{array}$ & $\begin{array}{r}11.6 \\
6.1 \\
11.7 \\
6.9\end{array}$ & $\begin{array}{l}2 \cdot 6 \\
4 \cdot 0 \\
3 \cdot 9\end{array}$ & $\begin{array}{r}11 \cdot 1 \\
6 \cdot 2 \\
11 \cdot 4 \\
6 \cdot 3\end{array}$ \\
\hline $\begin{array}{l}7 \\
8 \\
9\end{array}$ & $\begin{array}{l}34 \\
45 \\
49\end{array}$ & $\begin{array}{l}\text { Regular } \\
\text { Irregular } \\
\text { Irregular }\end{array}$ & $\begin{array}{l}\text { Cyclical } \\
\text { Cyclical } \\
\text { Cyclical }\end{array}$ & $\begin{array}{l}\text { predominance } \\
\text { Bilateral } \\
\text { Bilateral } \\
\text { Bilateral }\end{array}$ & $\begin{array}{c}0 \\
0 \\
0 \\
0 \\
\text { (1st period) }\end{array}$ & $\begin{array}{c}++ \\
++ \\
++ \\
0 \\
\text { (2nd period) }\end{array}$ & $\begin{array}{l}15 \cdot 1 \\
17 \cdot 6 \\
10 \cdot 2 \\
14 \cdot 2\end{array}$ & $\begin{array}{l}2 \cdot 5 \\
2 \cdot 7 \\
7 \cdot 7\end{array}$ & $\begin{array}{r}9 \cdot 9 \\
25 \cdot 2 \\
7 \cdot 5 \\
16 \cdot 7\end{array}$ \\
\hline 10 & 43 & $\begin{array}{l}\text { Had } \\
\text { hysterectomy }\end{array}$ & Constant & Bilateral & 0 & ++ & 20.9 & $10 \cdot 3$ & $19 \cdot 9$ \\
\hline
\end{tabular}

$*++=$ unchanged; $+=$ appreciably reduced; $0=$ total or near total relief of pain. 